\title{
PENGARUH MODEL PEMBELAJARAN SAINS TEKNOLOGI MASYARAKAT (STM) TERHADAP KEMAMPUAN PEMECAHAN MASALAH DAN SIKAP ILMIAH SISWA
}

\author{
Emy K. Gestarini, I Wayan Santyasa, I Made Kirna \\ Program Studi Teknologi Pembelajaran, Program Pasca Sarjana \\ Universitas Pendidikan Ganesha \\ Singaraja, Indonesia \\ Email:wayan santyasa@pasca.undiksha.ac.id, \\ made kirna@pasca.undiksha.ac.id
}

\begin{abstract}
Abstrak
Penelitian ini bertujuan 1) mendeskripsikan perbedaan kemampuan pemecahan masalah dan sikap ilmiah siswa antara siswa yang belajar dengan menggunakan model pembelajaran SainsTeknologi-Masyarakat (STM) dengan siswa yang belajar dengan menggunakan model pembelajaran konvensional;2) mendeskripsikan perbedaan kemampuan pemecahan masalah antara siswa yang belajar dengan model pembelajaran Sains-Teknologi-Masyarakat (STM) dan siswa yang belajar dengan model pembelajaran konvensional; dan 3) mendeskripsikan perbedaan sikap ilmiah siswa antara siswa yang belajar dengan model pembelajaran Sains-Teknologi-Masyarakat dan siswa yang belajar dengan model pembelajaran konvensional. Populasi penelitian adalah 8 kelas siswa kelas VIII SMP Negeri 1 Rendang, Karangasem Tahun Pelajaran 2015/2016. Sampel ditentukan dengan teknik group random sampling. Berdasarkan hasil random, terpilih kelas VIIIA sebagai kelompok siswa menggunakan model pembelajaran sains teknologi masyarakat dan kelas VIIIF menggunakan model pembelajaran konvensional. Data kemampuan pemecahan masalah dikumpulkan dengan tes, sedangkan sikap ilmiah dengan angket. Data dianalisis secara deskriptif dan MANCOVA.

Hasil penelitian menunjukkan bahwa: (1) terdapat perbedaan signifikan kemampuan pemecahan masalah dan sikap ilmiah antara siswa yang belajar dengan model pembelajaran sains teknologi masyarakat dengan siswa yang belajar dengan model pembelajaran konvensional; (2) terdapat perbedaan signifikan kemampuan pemecahan masalah antara siswa yang belajar dengan model pembelajaran sains teknologi masyarakat dengan siswa yang belajar dengan model pembelajaran konvensional; dan (3) terdapat perbedaan signifikan sikap ilmiah antara siswa yang belajar dengan model pembelajaran sains teknologi masyarakat dengan siswa yang belajar dengan model pembelajaran konvensional. Berdasarkan hasil penelitian yang dilakukan dapat disimpulkan model pembelajaran Sains Teknologi Masyarakat (STM) lebih unggul dibandingkan dengan model pembelajaran konvensional baik dalam pemcapaian kemampuan pemecahan masalah maupun sikap ilmiah.
\end{abstract}

Kata Kunci: model pembelajaran sains teknologi masyarakat, kemampuan pemecahan masalah, sikap ilmiah.

\begin{abstract}
This study aims to 1) describe differences in problem-solving ability and scientific attitude of students between students who learn by using model Science-Technology-Society (STM) with students learning by using conventional learning models; 2 ) describe differences in problem solving ability among students learning learning model Science-Technology-Society (STM) and student learning with conventional learning model; and 3) describe the distinctive scientific attitude among students learning students with learning model Science-Technology-Society and student learning with conventional learning models. The study population was 8th grade class VIII SMP Negeri 1 Rendang, Karangasem in the academic year 2015/2016. Sample group was determined by random sampling technique. Based on the results of random, elected VIIIA class as a group of students using model class science and technology community VIIIF using conventional learning models. Data collected by the problem-solving
\end{abstract}


skills test, while the scientific attitude to the questionnaire. Data were analyzed descriptively and MANCOVA.

The results showed that: (1) there are significant differences in problem solving skills and scientific attitudes among students learning with science learning model community technology with student learning with conventional learning model; (2) there are significant differences between the problem solving ability of students to learn the science learning model community technology with student learning with conventional learning model; and (3) there is a significant difference between the scientific attitude of students studying science learning model community technology with student learning with conventional learning models. Based on the results of research conducted inferential learning model Science Technology Society (STM) is superior compared to conventional learning models both in pemcapaian problem solving skills and scientific attitude.

Keywords: model of science learning technology community, problem solving ability, scientific attitude.

\section{PENDAHULUAN}

Pendidikan memegang peranan penting dalam peningkatan kualitas sumber daya manusia yang mampu menghadapi tantangan zaman. Agar tercipta sumber daya manusia yang kompetitif dan memiliki daya saing, diperlukan peningkatan kualitas pendidikan yang berkesinambungan. Untuk menjawab segala tantangan jaman, maka harus ada perubahan paradigma dalam pendidikan. Perubahan paradigma pendidikan yaitu dari teacher centered menjadi student centered, dari satu arah menjadi interaktif, dari isolasi menuju lingkungan jejaring, dari pasif menuju aktif menyelidiki, dari abstrak menuju konteks dunia nyata, dari pribadi menuju pembelajaran berbasis tim, dari hubungan satu arah menuju kooperatif, dari penyampaian pengetahuan menuju pertukaran pengetahuan. Perubahan paradigma pendidikan ini diharapkan akan dapat meningkatkan mutu pendidikan di Indonesia.

Menurut Sardiman (2003) belajar merupakan perubahan tingkah laku atau penampilan dengan serangkaian kegiatan misalnya dengan membaca, mendengarkan, meniru dan lain sebagainya. Keterlibatan siswa dalam proses belajar mengajar merupakan suatu implementasi dari keaktifan siswa dalam proses tersebut, siswa dapat berperan aktif dengan cara melakukan aktivitas yang dapat mendukung proses belajar diantaranya dengan berdiskusi, membaca, dan memahami materi pelajara, kerja kelompok, serta melaksanakan tugas-tugas yang diperintahkan guru. Pendidikan sains memainkan peranan penting dalam menyiapkan sumber daya manusia handal, untuk menghadapi era global yang penuh dengan kompetisi. Hal ini hanya bisa terwujud apabila pendidikan sains mampu menciptakan siswa yang kuat dalam sains dan berhasil menumbuhkan kemampuan berpikir logis, berpikir kritis, berpikir kreatif, berinisiatif dan adaptif terhadap perubahan dan pembangunan (Suastra, 2006).

KTSP yang diberlakukan sejak tahun 2006 memberikan tekanan pada pengembangan kompetensi siswa dalam aspek kognitif, afektif dan psikomotor yang direfleksikan dalam kebiasaan berpikir dan bertindak. Santyasa (2009) menyatakan salah satu kelebihan KTSP yaitu dinyatakannya pemecahan masalah (problem solving), penalaran (reasoning), komunikasi (communication), dan menghargai manfaat sains sebagi tujuan pembelajaran sains di sekolah. Menurut 
Krulik dan Rudnik (1996) kebiasaan berikir dan bertindak digambarkan dalam keterampilan berpikir dari tingkatan yang paling rendah ke tingkatan yang paling tinggi, yaitu retention thinking, basic thinking, critical thinking, creative thinking. Hal tersebut menunjukkan bahwa KTSP memberikan tekanan pada pengembangan kompetensi peserta didik. Kompetensi yang dimaksudkan adalah keterampilan, pengetahuan dan nilai dasar yang direfleksikan dalam kebiasaan berpikir dan bertindak.

$$
\text { Menurut Tim Broad-Based }
$$

Education (dalam Santyasa, 2008) dan dalam konteks KTSP, kebiasaan berpikir dan bertindak merupakan salah satu tujuan yang harus dicapai dalam pembelajaran siswa di sekolah. Marzano (1993), menyatakan bahwa kebiasaan berpikir dan bertindak meruakan dimensi ke-5 (dimensi puncak) dari proses dan produk belajar siswa. Menurut American Asociation for the Advancemen of Science (AAAS) (Santyasa, 2008) dan National Research Council (NRC) (Barak, 2008), bahwa tujuan utama pendidikan sains lebih diarahkan pada pencapaian pengembangan kompetensi intelektual siswa, seperti independent learning, problem solving, decision making, dan reasoning (basic, critical, dan creative thinking).

Idealnya pendidikan sains seperti yang terurai di atas tampaknya belum tercapai secara optimal. Pernyataan tersebut didukung oleh penelitian Hibah Bersaing yang dilakukan Sadia, dkk (2003) terhadap siswa SMA di Bali ditemukan bahwa sebagian besar (90\%) tujuan pembelajaran diarahkan pada transfer pengetahuan fisika dan kurang diarahkan pada pengembangan kreativitas berpikir dan keterampilan prosese sains.
Program for International Student Assesment (PISA) (2003) menyatakan rendahnya sikap ilmiah siswa Indonesia ditunjukkan oleh penelitian dan penilaian yang diukur melalui kemampuan scientific literacy. Hasil penilaian menunjukkan bahwa siswa Indonesia memiliki skor rata-rata literasi sains sebesar 395 (Lemke et. al,2004). Skor rata-rata literasi sains siswa Indonesia berada pada level 2 dari 6 level yang ada. Level tersebut memiliki kualifikasi level dengan kategori rendah, yang sama dengan skor rata-rata literasi sains siswa Negara Brazil dan Tunisia. Ruang lingkup penilaian pada literasi mencakup tiga dimensi, yaitu konten, proses, dan konteks sains. Berdasarkan hasil penilaian PISA tersebut ditunjukkan bahwa aspekaspek sikap ilmiah siswa Indonesia terukur masih rendah dalam cakupan dimensi literasi sains.

Kondisi ini tidak semata-mata kesalahan guru sebagai seorang pengajar namun jika diamati, pembelajaran satu arah ini kerap terjadi di daerah-daerah yang berada di pinggiran kota dengan kondisi sekolah yang masih minim fasilitas serta masyarakatnya yang berekonomi rendah atau kurang mampu, sehingga ketika pembelajaran berlangsung, harapan untuk pembelajaran terjadi dua arah secara efektif di kelas masih perlu dipertanyakan.

Kegiatan pembelajaran tidak terlepas dari berbagai variabel pokok yang saling berkaitan yaitu kurikulum, guru/pendidik, pembelajaran, siswa (Sumiati \& Arsa, 2007). Para pendidik dituntut harus mampu menggunakan berbagai model pembelajaran agar siswa dapat melakukan kegiatan pembelajaran dengan menyenangkan. Hal ini di latarbelakangi bahwa siswa bukan hanya sebagai objek tetapi juga merupakan subjek dalam 
pembelajaran. Langkah awal yang dapat dilakukan guru dalam memperbaiki proses pembelajaran adalah dengan mengubah paradigma teaching menjadi paradigma learning. Guru tidak lagi berperan sebagai penyampai materi dan siswa bukan berperan sebagai kendi kosong yang akan diisi oleh guru (Trianto, 2007). Guru seharusnya tidak mendominasi kegiatan pembelajaran, siswa hanya duduk, diam, mendengarkan, mencatat, dan mentaati segala perlakuan guru sehingga tidak ada sikap ilmiah ingin mencari tahu dalam pembelajaran. Siswa yang mempunyai sikap ilmiah baik akan selalu terlibat dalam proses belajar. Siswa mau belajar jika dalam lubuk hatinya ada keinginan untuk mengetahui sesuatu dalam proses belajar mengajar, siswa akan berusaha untuk mengajukan pertanyaanpertanyaan atau menanyakan masalahmasalah yang belum dipahami.

Sebagai solusi untuk mengatasi masalah-masalah pada proses pembelajaran adalah melalui implementasi pembelajaran yang inovatif. Salah satu model pembelajaran inovatif yang dapat diterapkan adalah model pembelajaran Sains Teknologi Masyarakat (STM). Isu-isu social dan teknologi di masyarakat. Oleh sebab itu model pembelajaran sains teknologi masyarakat dapat meningkatkan kemampuan pemecahan masalah dan sikap ilmiah siswa sangat menarik untuk diteliti.

Berdasarkan latar beakang diatas dan setelah perlakuan dikontrol dengan kemampuan pemecahan masalah dan sikap ilmiah awal maka tujuan dari penelitian ini adalah sebagai berikut (1) Mendeskripsikan perbedaan kemampuan pemecahan masalah dan sikap ilmiah siswa antara siswa yang belajar dengan menggunakan model pembelajaran

Sains-Teknologi-
Masyarakat (STM) dengan siswa yang belajar dengan menggunakan model pembelajaran konvensional. Mendeskripsikan perbedaan kemampuan pemecahan masalah antara siswa yang belajar dengan model pembelajaran Sains-TeknologiMasyarakat (STM) dan siswa yang belajar dengan model pembelajaran konvensional (3) Mendeskripsikan perbedaan sikap ilmiah siswa antara siswa yang belajar dengan model pembelajaran Sains-TeknologiMasyarakat dan siswa yang belajar dengan model pembelajaran konvensional.

\section{METODE PENELITIAN}

Penelitian ini menggunakan eksperimen semu (quasi) dengan rancangan nonequivalence preetestposttest control group design Penelitian ini melibatkan 8 kelas siswa sebagai populasi dan 2 kelas sampel. Penentuan 2 kelas sampel dan menentukan kelompok eksperimen dan kelompok kontrol dilakukan secara random.

Penelitian ini mengkaji satu variabel bebas dan dua variabel terikat. Variabel bebasnya adalah model pembelajaran, yang dibedakan atas model STM dan model konvensioal. Variabel terikatnya adalah kemampun pemecahan masalah dan sikap ilmiah siswa. Data kedua variabel terikat tersebut dikumpulkan dengan pedoman observasi yang telah tervalidasi. Data dianalisis secara deskriptif dan teknik MANCOVA. Analisis deskriptif digunakan untuk mendeskripsikan nilai rata-rata dan simpangan baku variabel kemampuan pemecahan masalah dan sikap ilmiah siswa. MANCOVA dipakai untuk menguji hipotesis penelitian.

HASIL DAN PEMBAHASAN 
Tabel 4.1 Statistik Deskriptif Kemampuan Pemecahan Masalah dan sikap ilmiah siswa Kelompok Siswa yang Belajar dengan Menerapkan Model Sains Teknologi Masyarakat dan Kelompok Siswa yang Belajar dengan Menerapkan Model Pembelajaran Konvensional

\begin{tabular}{|l|l|l|l|c|}
\hline \multicolumn{1}{|c|}{ Variabel } & $\begin{array}{l}\text { KPM_ } \\
\text { Statistik }\end{array}$ & $\begin{array}{l}\text { KPM_- } \\
\text { KV }\end{array}$ & $\begin{array}{l}\text { SI_ } \\
\text { STM }\end{array}$ & SI_KV \\
\hline Rata-rata & 77,00 & 66,00 & 71,96 & 68,3 \\
\hline Median & 76,00 & 68,00 & 71,00 & 68,00 \\
\hline Simpangan Baku & 5,600 & 7,69 & 4,16 & 3,56 \\
\hline Varian & 31,43 & 59 & 17,318 & 9,35 \\
\hline Minimum & 64,00 & 52,00 & 63,00 & 62,00 \\
\hline Maksimum & 84,00 & 80,00 & 80,00 & 75,00 \\
\hline Rentangan & 20,00 & 28,00 & 17,00 & 13,00 \\
\hline Jumlah Siswa & 26 & 26 & 26 & 26 \\
\hline
\end{tabular}

Secara deskriptif dapat dilihat bahwa nilai rata-rata kemampuan pemecahan masalah siswa yang belajar dengan model Sains Teknologi Masyarakat (STM) sebesar 77,00 dengan nilai simpangan baku sebesar 5,60 . Nilai rata-rata pada kemampuan pemecahan masalah dengan model STM lebih besar dari pada nilai rata-rata kemampuan pemecahan masalah siswa yang belajar dengan model pembelajaran kovensional $(68,00)$ dengan simpangan baku sebesar 7,69. Data di atas menunjukkan bahwa tampaknya model Pembelajaran Sains Teknologi Masyarakat (STM) memberikan pengaruh yang positif terhadap kemampuan pemecahan masalah siswa pada kelompok experimen. Dilihat dari nilai rata-rata pada sikap ilmiah siswa, kelompok siswa yang belajar dengan model Sains Teknologi Masyarakat (STM) memperoleh nilai yang lebih tinggi $(71,00)$ dengan simpangan baku 4,16 dibandingkan dengan kelompok siswa yang belajar dengan model pembelajaran konvensional yang memperoleh nilai rata-rata sebesar 68,00 dengan simpangan baku sebesar 3,56. Hal ini juga tampaknya menunjukkan bahwa model pembelajaran sains teknologi masyarakat (STM) memberikan pengaruh yang cukup positif terhadap sikap ilmiah siswa.

\section{Tabel 4.15 Hasil Analisis MANCOVA Hipotesis I}

\begin{tabular}{|ll|l|l|l|l|l|}
\hline Effect & & Value & F & Hypothesis df & Error df & Sig. \\
\hline Intercept & Pillai's Trace & .272 & $8.786^{\mathrm{a}}$ & 2.000 & 47.000 & .001 \\
& Wilks' Lambda & .728 & $8.786^{\mathrm{a}}$ & 2.000 & 47.000 & .001 \\
& Hotelling's Trace & .374 & $8.786^{\mathrm{a}}$ & 2.000 & 47.000 & .001 \\
\hline
\end{tabular}




\begin{tabular}{|c|c|c|c|c|c|c|}
\hline & Roy's Largest Root & $\mid .374$ & $8.786^{a}$ & 2.000 & |47.000 & .001 \\
\hline \multirow[t]{4}{*}{ Pre_KPM } & Pillai's Trace & .113 & $3.007^{a}$ & 2.000 & 47.000 & .059 \\
\hline & Wilks' Lambda & .887 & $3.007^{\mathrm{a}}$ & 2.000 & 47.000 & .059 \\
\hline & Hotelling's Trace & .128 & $3.007^{a}$ & 2.000 & 47.000 & .059 \\
\hline & Roy's Largest Root & .128 & $3.007^{\mathrm{a}}$ & 2.000 & 47.000 & .059 \\
\hline \multirow[t]{4}{*}{ Pre_SI } & Pillai's Trace & .290 & $9.579^{a}$ & 2.000 & 47.000 & .000 \\
\hline & Wilks' Lambda & .710 & $9.579^{\mathrm{a}}$ & 2.000 & 47.000 & .000 \\
\hline & Hotelling's Trace & .408 & $9.579^{a}$ & 2.000 & 47.000 & .000 \\
\hline & Roy's Largest Root & .408 & $9.579^{a}$ & 2.000 & 47.000 & .000 \\
\hline \multirow[t]{4}{*}{$\mathrm{MP}$} & Pillai's Trace & .493 & $22.832^{\mathrm{a}}$ & 2.000 & 47.000 & .000 \\
\hline & Wilks' Lambda & .507 & $22.832^{\mathrm{a}}$ & 2.000 & 47.000 & .000 \\
\hline & Hotelling's Trace & .972 & $22.832^{\mathrm{a}}$ & 2.000 & 47.000 & .000 \\
\hline & Roy's Largest Root & .972 & $22.832^{\mathrm{a}}$ & 2.000 & 47.000 & .000 \\
\hline
\end{tabular}

Pertama, dari sumber pengaruh kovariat Pre_KPM ditemukan bahwa nilai-nilai statistik Pillai's Trace, Wilks' Lambda, Hotelling's Trace, danRoy's Largest Rootmasing-masing dengan $\mathrm{F}=$ 3,007 dan angka signifikansi masingmasing 0,059, maka hipotesis nol yang menyatakan "tidak ada pengaruh kovariat Pre_KPM terhadap kemampuan pemecahan masalah dan sikap ilmiah secara bersama-sama" diterima. Jadi secara bersama-sama kemampuan pemecahan masalah dan sikap ilmiah secara signifikan $(P>0,05)$ tidak dipengaruhi oleh kovariat kemampuan pemecahan masalah awal (Pre_KPM).

Kedua, dari sumber pengaruh kovariat Pre_SI ditemukan bahwa nilai-nilai statistik Pillai's Trace, Wilks' Lambda, Hotelling's Trace, dan Roy's Largest Root masing-masing dengan F = 9,579 dan angka signifikansi masingmasing 0,001. Oleh karena angka signifikansi lebih kecil dari 0,05 , maka hipotesis nol yang menyatakan "tidak ada pengaruh kovariat Pre_KPM terhadap kemampuan pemecahan masalah dan sikap ilmiah siswa secara bersama-sama" ditolak. Jadi secara bersama-sama kemampuan pemecahan masalah dan sikap ilmiah secara signifikan $(P<0,05)$ dipengaruhi oleh kovariat sikap ilmiah awal (Pre_KPM).

Ketiga, dari sumber pengaruh model belajar ditemukan bahwa nilainilai statistik Pillai's Trace, Wilks' Lambda, Hotelling's Trace, dan Roy's Largest Root dengan $\mathrm{F}=22,832$ dan angka signifikansi 0,001. Angka signifikansinya lebih kecil dari 0,05 . Hal ini dijadikan dasar dalam pengambilan keputusan. Hipotesis nol yang menyatakan "tidak ada pengaruh model belajar kemampuan pemecahan masalah dan sikap ilmiah secara bersama-sama" ditolak. Jadi secara bersama-sama kemampuan pemecahan masalah dan sikap ilmiah secara signifikan $(P<0,05)$ dipengaruhi oleh kovariat model belajar.

Simpulan yang dapat ditarik adalah terdapat perbedaan kemampuan pemecahan masalah dan sikap ilmiah yang signifikan antara kelompok siswa yang belajar dengan menerapkan model pembelajaran sains teknologi masyarakat dengan siswa yang belajar menerapkan model pembelajaran konvensional. 
Jurnal Teknologi Pembelajaran Indonesia

ISSN: 2615-2797(Print) | ISSN: 2614-2015 (Online) Volume 8 Nomor 2 Tahun 2018

Tabel 4.16 Hasil Analisis Pengaruh-pengaruh antar subjek

\begin{tabular}{|ll|r|r|r|r|r|}
\hline \multirow{2}{*}{ Source } & Dependent & $\begin{array}{c}\text { Type III Sum of } \\
\text { Squares }\end{array}$ & Df & Mean Square & \multicolumn{1}{c|}{ F } & \multicolumn{1}{c|}{ Sig. } \\
\hline Corrected Model & Post_KPM & $1774.334^{\mathrm{a}}$ & 3 & 591.445 & 14.218 & .000 \\
& Post_SI & $364.875^{\mathrm{b}}$ & 3 & 121.625 & 12.371 & .000 \\
\hline Intercept & Post_KPM & 342.950 & 1 & 342.950 & 8.244 & .006 \\
& Post_SI & 88.354 & 1 & 88.354 & 8.987 & .004 \\
\hline Pre_KPM & Post_KPM & 234.188 & 1 & 234.188 & 5.630 & .022 \\
& Post_SI & 3.791 & 1 & 3.791 & .386 & .538 \\
\hline Pre_SI & Post_KPM & 2.626 & 1 & 2.626 & .063 & .803 \\
& Post_SI & 192.292 & 1 & 192.292 & 19.560 & .000 \\
\hline MP & Post_KPM & 1259.867 & 1 & 1259.867 & 30.286 & .000 \\
& Post_SI & 143.513 & 1 & 143.513 & 14.598 & .000 \\
\hline Error & Post_KPM & 1996.743 & 48 & 41.599 & & \\
& Post_SI & 471.894 & 48 & 9.831 & & \\
\hline Total & Post_KPM & 271040.000 & 52 & & & \\
& Post_SI & 256758.000 & 52 & & & \\
\hline Corrected Total & Post_KPM & 3771.077 & 51 & & & \\
& Post_SI & 836.769 & 51 & & & \\
& & & & & & \\
\hline
\end{tabular}


Hipotesis II dan III menggunakan hasil analisis"Tests of BetweenSubjects Effects". Hipotesis penelitian kedua menyatakan terdapat perbedaan yang signifikan kemampuan pemecahan masalah antara siswa yang belajar dengan model Sains Teknologi Masyarakat (STM) dan model pembelajaran konvensional $\left(\mathrm{H}_{1}\right)$ dan tidak terdapat perbedaan yang signifikan kemampuan pemecahan masalah antara siswa yang belajar dengan model Sains Teknologi Masyarakat (STM) dan model pembelajaran konvensional $\left(\mathrm{H}_{0}\right)$. Hipotesis penelitian ketiga menyatakan terdapat perbedaan yang signifikan sikap ilmiah antara siswa yang belajar dengan model Sains Teknologi Masyarakat (STM) dan model pembelajaran konvensional $\left(\mathrm{H}_{1}\right)$ dan tidak terdapat perbedaan yang signifikan sikap ilmiah antara siswa yang belajar dengan model Sains Teknologi Masyarakat (STM) dan model pembelajaran konvensional $\left(\mathrm{H}_{0}\right)$. Terkait dengan variabel kemampuan pemecahan masalah, hasil analisis di atas menunjukkan bahwa nilai signifikan untuk kovariat pretes kemampuan pemecahan masalah terhadap postes kemampuan pemecahan masalah sebesar 0.001, ini menunjukkan bahwa kemampuan pemecahan masalah awal siswa berpengaruh secara signifikan terhadap kemampuan pemecahan masalah akhir siswa. Nilai signifikan untuk kovariat pretes kemampuan pemecahan masalah terhadap postes sikap ilmiah sebesar 0.002, ini juga menunjukkan bahwa kemampuan pemecahan masalah awal siswa berpengaruh secara signifikan terhadap sikap ilmiah akhir siswa.

Model pembelajaran pada kemampuan pemecahan masalah (postes kemampuan pemecahan masalah) memiliki nilai signifikan sebesar 0.001 Nilai signifikansinya lebih kecil dari taraf signifikansi yang ditetapkan yaitu sebesar 0,05, sehingga $\mathrm{H}_{0}$ yang menyatakan tidak terdapat perbedaan yang signifikan kemampuan pemecahan masalah antara siswa yang dibelajarkan dengan model Sains Teknologi Masyarakat (STM) dengan kelompok siswa yang dibelajarkan dengan model pembelajaran konvensional ditolak. Sebagai konsekuensinya $\mathrm{H}_{1}$ diterima, yaitu terdapat perbedaan yang signifikan kemampuan pemecahan masalah antara kelompok siswa yang belajar dengan model Sains Teknologi Masyarakat (STM) dengan kelompok siswa yang dibelajarkan dengan model pembelajaran konvensional.

Pada variabel sikap ilmiah, hasil analisis $\mathrm{di}$ atas menunjukkan bahwa nilai signifikan untuk kovariat pretes sikap ilmiah terhadap postes sikap ilmiah memiliki nilai 0.001 , ini menunjukkan bahwa sikap ilmiah awal siswa berpengaruh secara signifikan terhadap sikap ilmiah akhir siswa. Tetapi, nilai signifikan untuk kovariat pretes sikap ilmiah terhadap postes sikap ilmiah memiliki nilai 0.803 , ini menunjukkan bahwa sikap 
ilmiah awal siswa tidak memiliki pengaruh secara signifikan terhadap sikap ilmiah akhir siswa.

Model pembelajaran pada sikap ilmiah (postes sikap ilmiah) memiliki nilai signifikan sebesar 0.001 Nilai signifikansinya lebih kecil dari taraf signifikansi yang ditetapkan yaitu sebesar 0,05, sehingga $\mathrm{H}_{0}$ yang menyatakan tidak terdapat perbedaan yang signifikan sikap ilmiah antara kelompok siswa yang dibelajarkan dengan model Sains Teknologi Masyarakat (STM) dengan kelompok siswa yang dibelajarkan dengan model pembelajaran konvensional ditolak. Sebagai konsekuensinya $\mathrm{H}_{1}$ diterima, yaitu terdapat perbedaan yang signifikan terhadap sikap ilmiah antara kelompok siswa yang dibelajarkan dengan model Sains Teknologi Masyarakat (STM) dengan kelompok siswa yang dibelajarkan dengan model pembelajaran konvensional.

\section{PEMBAHASAN}

Berdasarkan hasil analisis uji hipotesis 1 , dapat disimpulkan bahwa terdapat perbedaan yang signifikan aktivitas belajar dan prestasi belajar siswa secara bersama-sama antara siswa yang belajar dengan model Sains Teknologi masyarakat (STM) dengan siswa yang belajar dengan model pembelajaran konvensional. Nilai rata-rata di kelompok STM pada kemampuan pemecahan masalah dan sikap ilmiah lebih besar dibandingkan dengan kelompok pembelajaran konvensional. Data keempat nilai rata-rata tersebut terdapat perbedaan secara signifikan sehingga dapat disimpulkan bahwa model pembelajaran berpengaruh signifikan terhadap kemampuan pemecahan masalah dan sikap ilmiah secara bersama-sama. Model Sains Teknologi Masyarakat (STM) selain dapat meningkatkan kemampuan pemecahan masalah , juga diikuti oleh peningkatan sikap ilmiah siswa. Adapun alasan yang mendasari keunggulan model pembelajaran sains teknologi masyarakat dalam kemampuan pemecahan masalah dan sikap ilmiah siswa dapat ditinjau dari beberapa segi. Ditinjau dari landasan teoritik dan konseptual model pembelajaran sains teknologi masyarakat, model pembelajaran STM adalah belajar dan mengajarkan sains dalam konteks pengalaman manusia. Model pembelajaran STM dianggap cocok untuk mengintegrasikan domain konsep, keterampilan proses, kreativitas, sikap, nilai-nilai, penerapan, dan keterkaitan antar bidang studi dalam pembelajaran dan model sains. Menurut pandangan National Science Teacher Assocciation (NSTA), STM harus sejalan dengan pengalaman hidup siswa. Oleh karena itu, pembelajaran sains yang menggunakan model pembelajaran STM melibatkan masalah/isu aktual yang dihadapi oleh siswa dan masyarakat dalam kehidupan sehari-hari sehingga relevan dengan kehidupan siswa.

Pada hasil uji hipotesis 2 ditemukan bahwa terdapat perbedaan yang signifikan antara siswa yang belajar 
pengetahuan awal dan pembelajaran yang berorientasi pada tujuan.

Sikap ilmiah siswa dapat ditumbuhkembangkan melalui kegiatan laboratorium. Keterlibatan siswa secara aktif baik fisik maupun mental dalam kegiatan laboratoruim akan membawa pengaruh terhadap pembentukan pola tindakan siswa yang selalu di dasarkan pada hal-hal yang bersifat ilmiah. Sikap ilmiah siswa akan mempengaruhi keberhasilan siswa dalam kegiatan pembelajaran. Sikap siswa mempengaruhi keinginan siswa untuk ikut dalam aktivitas tertentu dan cara mereka merespon pada seseorang, objek atau situasi. Keinginan berpartisipasi adalah modal utama dan pembelajaran yang efektif. Siswa yang memiliki sikap ilmiah yang baik akan selalu terdorong untuk terlibat secara aktif dalam proses belajar. Salah satu dari aspek sikap ilmiah adalah rasa ingin tahu. Siswa mau belajar bila dalam lubuk hatinya ada keinginan untuk mengetahui sesuatu.

\section{SIMPULAN DAN SARAN}

Berdasarkan uraian di atas, dapat disimpulkan bahwa model pembelajaran berpengaruh terhadap kemampuan pemecahan masalah dan sikap ilmiah siswa. Secara lebih rinci simpulan dapat diuraikan sebagai berikut.

Pertama, perbedaan yang kemampuan terdapat signifikan pemecahan masalah dan sikap ilmiah antara siswa yang belajar dengan model
STM dan siswa yang belajar dengan model pembelajaran konvensional. Kemampuan pemecahan masalah dan sikap ilmiah siswa $s$ yang belajar dengan STM lebih tinggi dibandingkan dengan yang belajar dengan pembelajaran konvensional.

Kedua, terdapat perbedaan yang signifikan kemampuan pemecahan masalah antara siswa yang belajar dengan model STM dan siswa yang belajar dengan model pembelajaran konvensional. Kemampuan pemecahan masalah pada siswa yang belajar dengan model STM lebih tinggi dibandingkan dengan siswa yang mengikuti model pembelajaran konvensional.

Ketiga, terdapat perbedaan yang signifikan sikap ilmiah antara siswa yang belajar dengan model STM dan siswa yang belajar dengan model pembelajaran konvensional. Sikap ilmiah siswa pada kelompok STM lebih tinggi dibandingkan dengan siswa pada kelompok pembelajaran konvensional.

\subsection{SARAN}

Berdasarkan hasil penelitian diperoleh bahwa model pembelajaran sains teknologi masyarakat digunakan untuk meningkatkan kemampuan pemecahan masalah dan sikap ilmiah siswa, maka dalam proses pembelajaran dengan menggunakan model pembelajaran sains teknologi masyarakat dapat disarankan beberapa hal:

1) Dalam implementasi model pembelajaran sains teknologi 
masyarakat diawali dengan isu-isu lingkungan. Eksplorasi pengetahuan awal tersebut penting untuk dilakukan dalam rangka mengemas rancangan pembelajaran yang lebih bermakna. Pengetahuan awal digunakan sebagai alternatif pijakan dalam merumuskan tujuantujuan pembelajaran. .

2) Sebagai mediator, guru hendaknya membangkitkan aktivitas belajar siswa agar pembelajaran PAIKEM dapat terwujud. Aktivitas kelas dapat dilakukan dengan memberikan praktikum ataupun demonstrasi yang diupayakan menggali kreativitas siswa.

3) Untuk mencapai kemampuan pemecahan masalah dan sikap ilmiah secara mendalam pada pembelajaran sains, implementasi model pembelajaran sains teknologi masyarakat dianjurkan menggunakan masalahmasalah yang nyata, illdefined, dan ill-structured. Masalah-masalah tersebut dikemas dalam bentuk LKS.

4) Dalam model pembelajaran sains teknologi masyarakat dituntut untuk menggunakan laboratorium sebagai media penemuan bagi siswa. Guru hendaknya membimbing dan membantu siswa melakukan proses penemuan di laboratorium.

5) Kepala sekolah dan komite sekolah membantu pengadaan alat-alat dan media percobaan yang dapat digunakan untuk melakukan proses penemuan di dalam laboratorium.

\section{DAFTAR RUJUKAN}

Barak, M. Shakman, L. 2008. Reform Based Science Teaching: Teachers Instructional Practises and Conceptions. Journal: Eurasia Journal of mathematics, Science andx Tecnology Education.

PISA. 2000. The PISA 2000 Assesment of Reading, Mathematical and Scientific Literacy. Available at: http://www.pisa.oecd.org. Accessed 19 September 2013.

Sadia, W, Suastra, W, Tika, K. 2003. Pengembangan Model Belajar Perubahan Konseptual di SMA, Laporan Penelitian. IKIP Negeri Singaraja.

Sardiman, A. M. 2003, Interaksi Dan Motivasi Belajar Siswa. Jakarta. PT. Rajawali Presz Grafindo Persada.

Santyasa, I. W. 2008 Pembelajaran Konstektual. Makalah. Disajikan dalam Workk Shop tentang pembelajaran Konstektual Bagi Guru-Guru SMP Negeri 1 Banjar, 4 Januari 2008, di SMP Negeri 1 Banjar Buleleng.

Suastra, I.W. 2009. Pembelajaran Sains Terkini: 
Mendekatkan Siswa dengan Lingkungan

Alamiah dan Sosial

Budaya. Singaraja:

UDIKSHA.

Trianto. 2007. Model-Model Pembelajaran Inovatif Berorientasi

Konstruktivistik. Surabaya:

Perpustakaan Nasional.

Yager, R. E. 1992. The ScienceTechnology-Sociaty

Aproach Parallels

Contructivitist Practices.

Science Education

Internasional, 3 (2).

Yager, R. E. 1994. Assessment Results with the Science/ Technology/ Society Approach. Article.

Available at:

http://userpages.umbc.edu . Accesed: 14 Desember 2013

Yager, R. $\quad$ E. 1996. Sciens/technology/Socient $y$ as Reform in Science Education. State University of New York.

Yager, R. E., Choi, A., Yager, O.S. \& Akcay, H. 2009. A Comparison of Student Learning in STS vs Those in Directed Inquiry Classes. Article: Electronic Journal of Science Education.13(2),186-208. Available file:///C:/Users/GoshinBali Komputer. 